\title{
Social Entrepreneurship - Social Enterprises: European Experience and the Greek Case
}

\author{
Athanasia Triantafyllopoulou \\ Developmental Institutions of Local Government \\ Higher Technological Institute Educational Institute of Kalamata \\ 54 Bouboulinas str, Athens 10682, Greece \\ Tel: 30-21-522-8309 E-mail: athanasiatria@gmail.com
}

Received: November 21, 2011

Accepted: December 28, $2011 \quad$ Published: March 1, 2012

doi:10.5539/res.v4n1p115

URL: http://dx.doi.org/10.5539/res.v4n1p115

\begin{abstract}
In periods of recession, private sector of economy does not develop entrepreneurial action, due to limited demand which implies limited profits. This results in reduction in employment and increase in unemployment. Public sector of economy should proceed to public investments and enhance development. However, in the present economic crisis, public sector does not develop initiatives, due to budget deficit; to the contrary public sector is confined and contributes to the maintenance of recession. Social sector of economy does not aim at profit making but at job creation, mainly for the vulnerable groups of population. It intervenes by taking actions of mild economic growth and contributes to economic recovery. For this reason, national legislations in Europe provide the establishment of social economy enterprises. Local government, which, in a sense, belongs to the social sector of economy, has the possibilities to reinforce both social economy enterprises and actions of social entrepreneurship aiming for the enhancement of local economy.
\end{abstract}

Keywords: Social entrepreneurship, Social economy, Local government, Social economy enterprises, Social sector of economy, Third sector of economy, Economic recession

\section{Preamble}

Social economy is an arena of business activity including the public and the private sector. The economic entities that are activated within the context of social economy carry out actions which cover social needs and/ or are related to vulnerable social groups.

In general, social entrepreneurship constitutes a field of action between the public sector of economy and the sector of private initiative.

- The public sector includes both the state, in a rather narrow sense (government- public administration), and the broader public sector (public law legal entities, private law organizations controlled by the state - public enterprises).

- The sector of "private initiative" (enterprises or actions in general, organized under the framework and the rules of market economy).

- The collective action sector includes activities developed by collective entities, such as cooperatives, professional chambers, local unions and associations, nonprofit civil companies or other forms of collective socially-oriented initiatives.

The main goal of "private initiative" enterprises is to satisfy self-interest. On the contrary, the goal of public sector enterprises is to satisfy public interest.

The form and the structure of enterprises established by the state or by public organizations are defined by the objectives, the conditions of business activities and the needs that have to be met by any such enterprise. The establishment of the said enterprises and their basic operation rules are defined, per each category, by a special legislative framework, providing for their specific regulatory arrangements; other relevant issues are governed by the rules of private economy and any related legislative regulations. 
The collective action sector, the character, extent and organization of which are affected both by public sector rationale and market rationale, includes entities and activities that enable the participation and collective efforts of citizens with respectively common interests and benefits. They do not - primarily - aim at profit-making, even in cases when they also plan and seek for profit, but at the fulfillment of specific social needs, although they frequently make use of organizational schemes of business functions; or - in parallel to their social goals, they still head to revenue gains or to ensuring financial self-sufficiency by being paid for the products and services they provide. Any intended "profit", or -to be more accurate- "revenue", which forms an index for their rational business functioning, is not allocated to a specific entrepreneur or even to a specific social group, but it is either re-invested or used in order to meet the needs of the society as a whole.

Within the collective action sector, i.e. being classified as "social sector", as it aims at the fulfillment of specific social groups' needs, a category of financial units are activated, intending to cover social needs, either by performing particular actions, or because they address to specific population groups.

The third sector of economy, or, otherwise the sector of social actions, includes a group of activities with a view to achieve both financial results and social goals (Note 1). Entities involved in the above activities, without however being alienated from operational risks, intend to cover social needs, regardless the source they come from, and to develop production resources. Social entrepreneurship is structured and operates by the implementation of market rules; the entities involved make their management decisions on a democratic basis, providing any compensation gained from services provided or products manufactured to related activities or for reinforcing the same or similar entities.

\subsection{The European Union's position on social economy}

The European Parliament, by its resolution of 19 February 2009 on Social Economy, having regard to the fact that: "the social economy gives prominence to a business model that cannot be characterized either by its size or by its areas of activity, but by its respect for common values, namely, the primacy of democracy, social stakeholder participation, and individual and social objectives over gain; the defense and implementation of the principles of solidarity and responsibility; the conjunction of the interests of its user members with the general interest; democratic control by its members; voluntary and open membership; management autonomy and independence in relation to public authorities; and the allocation of the bulk of surpluses in pursuit of the aims of sustainable development and of service to its members in accordance with the general interest", points out that "the social economy plays an essential role in the European economy, by combining profitability with solidarity, creating high-quality jobs, strengthening social, economic and regional cohesion, generating social capital, promoting active citizenship, solidarity and a type of economy with democratic values which puts people first, in addition to supporting sustainable development and social, environmental and technological innovation".

Taking into consideration the enunciation of the aforementioned resolution by the European Parliament, the domestic rules stipulated by other states and the literature available, social economy enterprises may be defined as having the following characteristics: 1 . They aim at performing actions of social nature, 2 . They address to vulnerable social groups, 3 . They are governed on the basis of democracy and regardless of the capital provided by each member, 4 . They provide any surplus arising from financial management, primarily, for the development of activities related to the objects of such enterprises, with a view to boost employment and create new job opportunities, 5. They operate according to market rules, 6 . They facilitate the participation of as many as possible members.

Such characteristics reveal that social entrepreneurship aims at actions of social nature, supporting in parallel the access to and participation in the labor market of vulnerable population groups; it is established on the as broad as possible participation of entities, with equal rights and obligations regarding the legal scheme they take part in, without their participation in such cases being dependent on their financial contribution to the enterprise. Profit-making is not an object for such entities. Any surplus is provided for the enhancement of similar activities addressed to a broader development of the objectives of social economy enterprises. However, they do operate under market rules both because they have to facilitate their business performance, and because they should not be bound by rules that may recess their participation in the labor market.

Such entrepreneurial entities, in order to run this category of enterprises and due to the lack of specific legislative regulations, "borrow" discrete legislative schemes for establishment and operation purposes, as well as administration, organization and operation rules of legal schemes that belong to the abovementioned sectors of economy.

However, the legal order of E.U. member-states and recently Greece have established a special category of legal entities for social entrepreneurship, with discrete characteristics and certain administration and operation 
conditions. The rules of establishment and the general characteristics resemble either to the action rules of private initiative or those adopted by public enterprises and organizations. The main difference of social enterprises comparing to the other schemes is the goal they serve and the population groups that benefit from such actions, their operation means and the favorable regulations stipulated usually by states for facilitating the establishment of social economy enterprises.

\section{Forms of Entrepreneurial Activity}

Greek legislation provides for the establishment and operation of economic legal entities, governed by the rules of public or private law, which are activated in commercial or civil actions or perform socially-oriented actions.

The selection of a legal scheme category for the implementation of economic activities is based on the characteristics that match with the goal they serve in combination with the following rules on the establishment and operation of each legal scheme. The selection of a specific legal scheme basically depends on the following characteristics: a) the objective served by the establishment of the legal scheme, b) the means of administration, c) the legitimately minimum capital provided, d) its operational rules, e) its funding resources.

The legal status of the aforementioned economic schemes is governed both by commercial legislation and the civil code. In addition, special statutes stipulate the establishment and operation of legal entities for the performance of special activities that seek to promote the benefits of their participants or to perform activities of collective nature. The legal schemes of the public and the private sector, as well as those of the collective action sector are set forth below in order to highlight their difference regarding social entrepreneurship.

\section{Forms of Private Initiative Entrepreneurship}

Commercial law regulates the rules of entrepreneurship for private initiative entities. It provides for the establishment and operation of partnerships that include general partnerships and limited partnerships. Special statutes provide for the establishment of limited liability companies and corporations (societe anonyme). Personal enterprises are structured on jural reciprocal contracts with the participation of at least two or more parties that are able to perform legal acts and aim at a common goal, especially financial. Parties have joint and several liability by their entire personal property against any claims raised by third parties. On the contrary, limited liability partners are liable up to the amount of their contribution (Note 2). Societes anonymes may be established by one or more natural or legal persons. With regard to their debts to third parties, societes anonymes are solely liable by their assets. Each societe anonyme is characterized as a commercial company, although its objective may not be the exercise of commercial activities. It is legally characterized as a capital company (Note 3). Finally, limited liability companies are legally characterized as commercial companies, even when their objective does not include the performance of commercial operations. The company, though its assets, is solely liable for any corporate liability. The management of corporate affairs and the representation of the company may be delegated to partners or non-partners, according to its articles of association, upon a decision of the partners' assembly. The decision making procedure is based on personal voting (Note 4).

Individuals, in order to participate in an entrepreneurial activity, may choose a scheme, which, despite having a financial objective, it does not intend to profit-making actions, but it promotes the benefits of its members, or it becomes involved in entrepreneurial actions exclusively for ensuring their remuneration. In particular, this category includes the following: the Civil Law Partnership is a cooperation agreement between at least two natural or legal persons, which mutually take over the responsibility to achieve, through mutual contributions, a common goal, and particularly a financial one. Any liabilities towards third parties incur all partners, as per their quota. Unless otherwise agreed, partners do equally participate in profits and losses, regardless their contribution. The institute is a number of assets under legal personality. Even not explicitly stipulated by law, it serves a specific objective which is usually of social character. An institute is monitored by a competent public authority, according to its goal; it operates under the rules of private economy, unless otherwise stipulated in its deed of incorporation. The association is a civil code legal entity established by natural non-challengeable persons with a view to promote the interests and social benefits of its participants. Extraordinary members may also participate in the fulfillment of the association's goal and its actions in general, but they are eliminated from administrative procedures. An association is administrated by a Board of Directors which is elected by its members' assembly. The Board of Directors administrates and manages the affairs of the association and represents it before any third party. The operation of an association, unless otherwise provided, is governed by private law rules (Note 5).

\section{Collective Action Schemes}

Special legal regulations provide for the creation of collection schemes, either productive or social, with a view 
to perform collective actions. This category includes the following schemes: Cooperative: Cooperative is an association of persons with legal personality, aiming at a financial objective, by the participation of its members. Cooperatives are distinguished based on their goal, such as civil, rural, building and credit cooperatives (Law 1667/1986 on civil cooperatives, Law 1541/1985 on rural cooperatives, Law 2072/1996 on credit cooperatives, Presidential Decree 93/1987 on the Reformation and integration of the legislation governing Building Cooperatives". Cooperatives fall under state supervision, exercised by different bodies, according to the cooperative category. Its members participate by their contributions, which are irrelevant to the participation in decision-making, but they generate the right for dividend allocation. The minimum number of members is legally defined. Limited liability social cooperatives constitute a special category of cooperatives, as defined in the provisions of Law 2716/1999. Social cooperatives aim at social-economic integration and labor market inclusion of persons suffering from serious psycho-social problems; moreover, their establishment is expected to contribute to the treatment of such persons and to their best possible financial autonomy. Social cooperatives are supervised by the Ministry of Health and Social Solidarity.

Local Government Enterprises are also included in the collective action sector. More specifically, special regulations stipulate the creation of enterprises which are established by or involve the participation of local government organizations of first and second degree, pursuant to the code on municipalities and communities (3463/2006 as currently in force) (Note 6) and the law on the "New Architecture of Regional Administration and Decentralized Administration - Kallikratis Program" (Law 3852/2010). Local government enterprises may be distinguished in enterprises activated in the field of social solidarity, culture, sports, education and environment which operate under special arrangements, as provided in the code on municipalities and communities (social enterprises), and in enterprises of fully commercial nature which operate under the form of a societe anonyme. In societes anonymes, other natural or legal persons may also participate, while in the case of social enterprises, any third party is excluded. Developmental enterprises, where local government participates, constitute a discrete type of enterprises. Their goal is to support the agencies of local government and regional local government as well as to promote any growth initiatives taken by local government. Developmental enterprises have contributed to the administration and management of municipal and community affair, providing any necessary technical and scientific support to local government organizations. Social enterprises are administered by a Board of Directors appointed by the municipality or community council and their decisions are supervised by the municipality or community council. The Board of Directors of societes anonymes is elected by the General Assembly. Social enterprises are governed by the operational status of local government organizations; societes anonymes are governed by their respective provisions, while special issues are settled through specific regulations (Note 7).

\section{Public Enterprises}

Public sector enterprises are incorporated upon an initiative taken by the government or the broader public sector. They are usually established in the form of a societe anonyme and meet public interest goals. They operate under the laws of private economy, unless otherwise provided in their deed of incorporation or in a respective legal regulation. The capital of public enterprises comes, mostly or entirely, from the state. Their administration is appointed and their public funding is supervised by the Minister in charge (Note 8).

\section{Comparative Presentation between the Aforesaid Legal Schemes}

The aforesaid types of legal schemes indicate that any natural or legal person is able to perform both commercial and social activities, provided that no limitation imposed by legal regulations applies for a specific group of legal and natural persons. A comparative presentation of the conditions under which the abovementioned legal schemes operate leads to the following conclusions: Commercial law enterprises enable the participation of any natural or legal person. Their goal is commercial and the stakeholders aim at profit-maximization. Even though each vote is personal, the administration of enterprises is based on capital-holding. State enterprises are established by public funding; no third party is allowed to participate and they serve goals of common interest. The legal schemes of collective actions include units that have an economic or social goal and intend to meet the interests or benefits of the community they address to.

Local government enterprises fall under the aforesaid category. They either have solely commercial goals, operating according to the organization structure of private initiative enterprises or they exclusively constitute legal schemes that they may only be incorporated by the participation of local government, aiming at social goals. Developmental enterprises play the role of supporting mechanisms.

\section{Social Entrepreneurship}

Legal schemes have been instituted within the European area; they are activated in social entrepreneurship and 
have been operating according to the characteristics of social economy enterprises.

Indicatively, Italian Law 118/2005 and legislative decree no.155/2006 stipulate the establishment and operation of social enterprises.

In England, there are "Social Enterprises" and "Community Interest Companies" engaged in the employment of disabled persons. In France, the law of the $17^{\text {th }}$ July 2001 provides for the establishment of "Sociéte Cooperative d'Intérêt Collectif" (Collective Interest Cooperative Company). A Cooperative Enterprise allows for the performance of social activities, without however having a discrete legal personality (Note 9).

According to the explanatory report of the recently ratified law by the greek parliament (Note 10), "Approximately $10 \%$ of the european enterprises are regarded as social enterprises and employ 11 million employees. $10 \%$ of the new jobs created in the E.U. during the last years involve Social Economy activities. Social Economy represents $5.9 \%$ of total employment and $6.7 \%$ of salaried employment with an significant trend rise in such sector. In Spain, during the decade 1990-2000, the increase of employment in the field of social economy rose by $57.95 \%$ (i.e. from 224,000 to approx. 354,000 jobs in 2000). In Italy, from 1991 to 2001, the increase in employment to social cooperatives reached the percentage of $400 \%$ (from 27,000 jobs in 1991 to 149,000 in 2001)". The explanatory report additionally indicates that: "the European Union reckons this sector as a privileged field for the implementation of policies on employment, local development, fight against poverty and social exclusion. It creates new conditions for investment in "social capital" and "social innovation".

Current financial conditions do not facilitate the absorption of manpower both in the public and the private sector of economy. As a result, the population groups that suffer from the financial crisis should get involved in social economy actions. The provision of services or disposal of products would render them competitive and at the same time would encourage the incorporation of socially vulnerable groups in labor market.

\subsection{Social entrepreneurship in Euro cities}

In Europe, usually at city-level, measures have been taken for the enhancement of social entrepreneurship, aiming at the resurgence of economy. At the same time, European states cooperate with each other for the promotion of social entrepreneurship.

The actions, included in the programs of European cities and administered and decided by local authorities, refer to: programs for the support of enterprises with a view to differentiate the services they provide, programs of energy efficiency for small and medium enterprises and training programs for the personnel of such enterprises. Furthermore, such actions include programs for urban development and public investment, seeking for urban housing under cost-effective terms, and training programs with the purpose to maintain all workers employed in the field of constructions. Local authorities have taken measures to create new jobs through the provision of tax incentives, the access to training services for the manpower activated in areas with growth potential, the establishment of a fund for financing enterprises and innovation, the support of investments and the creation of new job opportunities. In addition, municipalities incorporated new enterprises. In the sector of social enterprises, special emphasis is laid on one stop shops, which provide services to citizens and entrepreneurs regarding debt payment, housing and economic growth. Local authorities have also decided and planned for the creation of new socially-oriented jobs in municipal enterprises. They have boosted the establishment of social enterprises and new agencies have been created for waste management, under the form of discrete legal persons. In addition, special measures have been taken for the occupation of unemployed people in public agencies (emergency occupation). The sector of entrepreneurship support has set the preconditions for the establishment of enterprises with innovate objectives and has taken all such necessary steps for the enhancement of youth entrepreneurship. Special care has been also given to social services, as measures were taken for the housing of people facing difficulties as well as for cutting down on heat expenses. The same sector has also taken care of the creation of a municipal fund as well as the constitution of observatories regarding social and economic issues, including training and education issues.

At the same time in Europe, a network of nine cities has been created (Birmingham, Bologna, Brno, Copenhagen, Krakow, Lille Metropole-Roubaix, Rotterdam, Stockholm and Sofia) for the provision of social services and mainly for the integration of young people and people with disabilities in the labor market. Therefore, such nine-city network, promotes the establishment of entrepreneurial schemes which are activated in the field of social economy (Note 11).

\section{The Greek Case}

According to all statistics available, as set forth in the explanatory report, "in Greece - compared to other European countries - the contribution of social economy in employment remains at significantly low level. More 
specifically, our country has the lowest percentage among the 15 E.U. member-states that have a previous relative experience. Employment in the field of Social Economy represents only $1.8 \%$ of total employment and $2.9 \%$ of salaried employment. Greece has approximately 8,400 cooperatives with approx. 950,000 members, 1,500-2,000 voluntary, with only 200-300 of them having active participation, out of which 115-200 of them are activated in the field of environment and ecology. There are also mixed organizations, volunteer organizations offering advocate services, in the form of unions, associations recognized as charity organizations, civil law non-profit partnerships, institutions, and financially-oriented associations, organizations or entrepreneurial schemes developing procedures for the labor market inclusion of excluded population groups. There are 71 women unions with 1,903 members, 68 cooperative treatment unions in psychiatric hospitals, 15 Limited Liability Social Cooperatives (KOISPE) aiming at the integration of mentally ill persons in the labor market, as well as in the provision of goods and services".

Greek legal order has recently filled the gap - existing till lately - regarding the setting up of legal schemes on social entrepreneurship and social economy.

Pursuant to the explanatory report, the basic objectives of such law are as follows: a) creating new jobs and the social integration of vulnerable groups, b) covering social needs, especially through the enhancement of social and inclusive entrepreneurship and social innovation, and c) the enhancement of local growth and social cohesion.

The provisions of the new law seek to boost employment, as the establishment of social economy enterprises can reduce unemployment levels. At the same time, it addresses to socially vulnerable groups as they can be recruited in such jobs. Social economy enterprises do not substitute for public agencies dedicated to cover social needs, but, within the framework of solidarity, they co-exist with the competent public agencies and play a supplementary role in covering social needs. Finally, social entrepreneurship strengthens local development, as their non-profit making character allows members of social enterprises to make smoother exploitation of financial and other resources; in addition, it enables entrepreneurship though social economy actions.

\subsection{Greek legislation}

According to Greek legislation, social cooperative enterprises, legally attributed with commercial capacities, are established as agencies of social entrepreneurship. Both natural and legal persons can take part in such enterprises, with the right to one vote, regardless the number of the cooperative shares they hold.

Social cooperative enterprises may be divided into the following categories, according to the goal they serve: a) Social Cooperative Enterprises for Integration. This category of social enterprises is activated in the integration of vulnerable groups into economic and social life. The main characteristic of such category is that they are compulsorily staffed - at a minimum percentage of $40 \%$ - by persons belonging in Vulnerable Population Groups. Theory and legislation defend as vulnerable social groups persons with special needs, drug addicts, alcoholics, persons under rehabilitation or fully rehabilitated, persons suffering from mental or psychological disorders or chronic health problems, persons discharged from prison, single parents, minor offenders, persons with lingual, cultural or other particularities, refugees, immigrants, maltreated women, elderly people, unemployed persons, poor persons and persons in need or persons residing in frontier areas. However, taking into consideration that social economy "is equally important to the enhancement of industrial and economic democracy", for the purpose of taking full advantage of the provisions of the said law, vulnerable social groups should also include such population groups which, under special conditions caused by force majeure natural disasters or by emergency incidents that encumber economy, either locally or nationally, and are obvious and broadly known, need to have their employment and production activity in general supported, in order to meet the emergency conditions they face.

b) Social Cooperative Enterprises for Care: these enterprises aim at the production and provision of social and welfare products and services to specific population groups. The law indicatively refers to elderly people, infants and children, persons with disabilities and persons suffering from chronic diseases.

c) Social Cooperative Enterprises for Collective and Production Purposes: this category of cooperative enterprises refers to the production of products and provisions of services for the fulfillment of collective needs. The law indicatively refers to culture, environment, ecology, education, public utility, strengthening of local products, maintenance of traditional activities and occupations, as they promote local and collective interest, enhance employment, strengthen social cohesion and empower local or regional development.

It is obvious that social economy enterprises expand in a rather broad field. It includes activities which are not limited solely to the provision of social services and do not exclusively address to vulnerable population groups 
who receive that services or to their inclusion in the labor market. The objective of social economy enterprises, as per greek legislation, is the performance of any commercial activity, which however, aims at the fulfillment of collective interests or includes actions that intend to enhance local and regional development. Moreover, another characteristic that differentiates commercial activities taken by social enterprises compared to those taken by commercial enterprises is their different form of administration and operation.

Members of a social cooperative enterprise may be employed and compensated by such enterprises, according to the provisions of labor legislation. Members of limited liability social cooperatives, which are recognized as enterprises of social entrepreneurship, provided that they are not employed in such enterprise, may be activated in such enterprises under contracts (Note 12) involving the assignment of a specific project or service. Although the law does not stipulate that these enterprises aim at profit-making, it is explicitly provided that gains are not allocated among their members, but 5\% thereof is annually allocated for the creation of reserve, $35 \%$ is distributed to enterprise employees as productivity incentive, defined in the articles of association of each enterprise, and the remaining amount is used in order to cover the activities of the enterprise and the creation of new jobs.

\subsection{Funding}

According to the Greek legislation, the incentives for the establishment of social economy enterprises include funding by the EU and by the program of public investments. Furthermore, these enterprises can be included in programs and actions funded by other international and national organizations, as well as by local government organizations of first and second degree. Other programs may be, as well, another funding resource for social economy enterprises. Funding resources may also include inherited assets, donations by natural or legal persons or the grant of asset use, as well as any other income arising from its prescribed activities.

Economic entities have another incentive to establish social economy enterprises. Their gain used as reserve by each commercial enterprise, are not treated as profits, and their personnel belonging to vulnerable population groups are tax-exempted.

Pursuant to the Greek legislation, social enterprises are registered in a special registry, kept by the competent Ministry (Note 13); such Ministry audits the respective records and documents, unless protected by professional confidentiality. In case of infringements, auditing agencies proceed to the imposition of penalties, as prescribed by law (Note 14).

\section{Observations}

The private initiative sector, known as private economy sector, is characterized by private initiatives and is activated for the maximization of profit-making. Although the private sector is able to develop entrepreneurial action in all the branches of economy, it usually makes use of such resources that are more cost-effective (maximum profit with minimum expenses) for the production or provision of any service. As a result, some sectors of economy, whose use is costly or require non-cost-effective production means, remain unexploited. Therefore, during periods of financial crisis, unemployment rates increase and some sectors that need a mildly intensive exploitation remain totally inactive.

The public sector uses radically different ways, means and goals compared to private economy. Public enterprises intervene in economic branches of significant interest for the society, aiming at the retention of prices and the control of production or provision of specific services, linked to the national wealth. Public sector acts as the regulator of economic branches at specific local, regional and national level. Public enterprises, in order to meet their objectives, operate in accordance to market rules, under any limitations set by the institutional regime, aiming at flexibility during production and provision of their products and services.

The collective action sector intervenes between those two sectors. This sector is founded on private initiative. It, however, differs from private initiative sector as it focuses on collective actions by individuals and private legal persons with a view to promote community interests. The collective action sector is activated in areas which do not require intensive rates of production and makes use of employees that belong to vulnerable groups of population.

\subsection{Social sector of economy}

Within the collection action sector, social sector stands out. The objective of the social economy sector is not restricted in promoting the interests of the participants in its economic units, but it pursuits covering of social needs through the active participation of population groups that are characterized as vulnerable.

Social economy enterprises have some characteristics which differ both from private \& public sector and the 
collective action sector. More specifically, they are different from: a) the private sector or the private initiative sector, where any natural or legal person carries out commercial activities, with a view, mainly, to maximize his/its profit through commercial activities, b) the public sector which intervenes in the field of economy aiming at the development of economic activities for the promotion of production and provision of products and services of public interest, $\mathbf{c}$ ) the collective action sector, which seeks to meet social interests of community members that are activated on a collective basis through the establishment of economic units, aiming at the mutual creation and provision of productions that they own, or at the mutual provision of services that fulfill collective benefit.

Social economy enterprises seek to perform activities through the initiative of persons, who, through their personal work, aim at social interest and not profit-making, which, however, is combined to the solidarity of economic unions' members. In addition, this economic sector intends to create new jobs by the exploitation of social capital. It is a human-oriented form of economy and it promotes sustainable economic growth, as well as social, environmental, cultural and spiritual one and contributes, through its entrepreneurial actions to the social integration and support of vulnerable social groups.

The operation of such enterprises is founded on democratic decision-making, which remains untouched by capital-holding, and on the restricted distribution of surplus, aiming at re-investment for benefiting such enterprise or enhancing employment.

Social economy enterprises set social goals, cover social and contribute to any kind of development. They address to several population categories, which are characterized as vulnerable.

Regarding the participation of entities to social economy enterprises, the following have been observed: since decision-making is structured on a voting basis and it is independent to capital holding, the fact that the majority is formed on a membership basis, just like in legal persons which are enabled to participate as members in such sector of economy, contravenes to the principles of equality. In particular, legal persons represent either a capital or a union of persons; such union may not be connected to legal schemes that develop actions of common interest or represent private interest, such as commercial partnerships. Specifically, in case of commercial law partnerships, although the majority is formed by partners' personal votes, each partner has a specific capital which he/she represents through his/her vote. Legal persons that fall under the sector of collective economy and fulfill the interest of a specific community, such as unions, would follow a different procedure. Even in this case, the representative of social enterprises' collective bodies represents a group of interests that may not coincide with the interests of members of enterprises that fall under this law. Legal persons, which could possibly participate in social economy enterprises in order to provide any required support to its members, include, among others, local government organizations and the enterprises thereof.

\subsection{Local government and the social sector}

Local government organizations are public entities that represent the residents of an area and promote their social, cultural and economic interests. As a result, they represent the interests of those entrepreneurial groups and they have to provide any necessary assistance regarding the achievement of their goal. Moreover, every local government organization should participate in all social economy enterprises, activated in the field of their administrative region, since those enterprises required so. Otherwise, in the case of selective participation, local government organizations might risk being treated with discrimination. In Greece, with regard to the participation of local government organizations, and particularly the enterprises thereof, their status of operation reveals that a) either they are single-share enterprises, and therefore they legally represent all population groups, b) or they are societes anonymes, with the participation of any natural or legal person, and therefore the aforementioned stipulations would apply, c) or they are developmental enterprises, which apart from representing local government and collective, social and production schemes, their goal is exclusive and involves the promotion of entrepreneurial actions at local level. Therefore, regardless of their participation in legal schemes activated at local level, they can cooperate with social economy enterprises.

As far as the minimum number of members is concerned, the following conclusions could be drawn: the main characteristic of the social economy sector and the actions included therein is the solidarity of its members. Solidarity is demonstrated by the participation of as many as possible persons, involved in specific actions. Respectively, in the collective action sector, solidarity, which is also a typical characteristic, is achieved through the participation of a number of persons adequate enough to perform specific actions. For example, the establishment of a union requires the minimum number of 20 persons, while a cooperative, accordingly to its objective, requires the participation of 15 members. However, in this case, the participation of capable population groups to whom social economy enterprises address, in combination to their entrepreneurial activity, would justify the participation of a lower number of members, proportionally to partnerships. The limitation to a 
specific number of persons usually leads to the actual fact that some members, who are truly interested in social entrepreneurship activities, have active participation, while some others, who have been enlisted in the enterprise just to complete the required minimum memberships, just remain inactive. As a result, no minimum memberships should be set by the lawmaker for the establishment of social economy enterprises.

Social Economy Enterprises do not aim at profit-making. However, this does not exclude the creation of a surplus, as a result of prudent financial management. In the event of a surplus, the latter should be deposited to a special account with a view to be used for covering the needs of any enterprise registered in the record of social economy enterprises and thus ensuring the principle of cooperation and solidarity among persons involved in this field of economy.

Social economy enterprises and local government can cooperate at local level. The institutional framework enables local government to assign fixed-budget projects and services, through a flexible procedure (Note 15), so as to enhance the initiatives of such enterprises, which as mentioned above, contribute to local and regional development.

\section{References}

Anastasopoulos, I. (1987). Public enterprises, Legal \& institutional view. Athens: Ant. N.Sakkoulas.

Chrysanthankis, C. \& Pantazopoulos, P. (2006). Recommendations on Administrative Law. Athens: Legal library.

Dart, R. (2004). The Legimacy of social enterprise. Nonprofit Management and Leadership, 14(4). http://dx.doi. org/10.1002/nml.43

Ferrera, M. (1999). The reform of the social state in Southern Europe, N. Matsaganis (ed). Perspectives of the social state in Southern Europe. Athens: Ellinika Grammata.

Georgakopoulos, L. (1974). The Law of Companies. Athens.

Kassabetis, D. (2003). The contribution of social enterprises to the development of local societies. Family Education and Child Care Center (KEMOP). Gutenberg: Panteion University.

Kontiadis, X. (2001). Transformations of the social state during globalization. Athens: Papazisi.

Kritikou. A. (1994). Limits of legal operation for collective bodies of associations, trade unions and cooperatives. Athens.

National Center for Social Research. (2008). Specialization of integrated programs for the development of entrepreneurship in the field of Social Economy. Athens.

Report. (2011). Cities for Active inclusion. [Online] Available: http://www.eurocities-nlao.eu

Sakellaropoulos, T. (2004). Participation-oriented procedures and the European Social Model: The open method of coordination. Athens: Institute of Strategic and Development Studies (ISTAME).

Triantafyllakis, G. (2000). Partnership - Joint Venture - Society. Athens.

Triantafyllopoulou, A. (2009). The institution of local government enterprises as per the new code on municipalities and communities. Athens: Ant. Sakkoulas.

Vlastos, S. (1999). Civil Associations - Trade and Vocational Unions (3 ${ }^{\text {rd }}$ ed.). Athens.

\section{Notes}

Note 1. For social entrepreneurship refer, among others, to: Dart R. (2004), "The Legimacy of social enterprise" in Nonprofit Management and Leadership, vol.14. no 4., Ferrera M. (1999), "The reform of the social state in Southern Europe" in N. Matsaganis (ed). Perspectives of the social state in Southern Europe, Athens, Ellinika Grammata, Kassabetis D., (2003) "The contribution of social enterprises to the development of local societies", Family Education and Child Care Center (KEMOP), Panteion University - Gutenberg., Kontiadis X. (2001), Transformations of the social state during globalization", Athens, Papazisi, Sakellaropoulos Th. (2004), Participation-oriented procedures and the European Social Model: The open method of coordination, Athens: Institute of Strategic and Development Studies (ISTAME).

Note 2. For partnerships refer to: L Georgakopoulos “The Law of Companies”, Athens 1974, G. Triantafyllakis "Partnership - Joint Venture - Society", first volume, Athens 2000.

Note 3. Nowadays, minimum required capital mounts up to the sum of 60000 euros.

Note 4. Article 2, par. 1, Law 3190/1955: Each partner is entitled to at least one vote. In case he/ she has more 
company shares, the number of his/ her qualifying votes is proportional to such shares.

Note 5. Refer to S. Vlastos "Civil Associations - Trade and Vocational Unions", 3rd edition, Athens 1999, A. Kritikou, Limits of legal operation for collective bodies of associations, trade unions and cooperatives", Athens 1994.

Note 6. Refer to our project (2009) "The institution of local government enterprises as per the new code on municipalities and communities" Athens, Ant. Sakkoulas.

Note 7. The Law on "New Architecture of Regional Administration and Decentralized Administration Kallikratis Program" stipulates that regions may only establish developmental agencies.

Note 8. Refer to Anastasopoulos I. (1987), "Public enterprises, Legal \& institutional view, Ant. N.Sakkoulas, Athens, Ch. Chrysanthankis - P. Pantazopoulos (2006) "Recommendations on Administrative Law", Legal library, Athens.

Note 9. Refer to the Study of the National Center for Social Research, Specialization of integrated programs for the development of entrepreneurship in the field of Social Economy, Athens 2008.

Note 10. Law 4019/2011 on "Social entrepreneurship and social economy enterprises".

Note 11. Cities for Active inclusion, February 2011, www.eurocities-nlao.eu.

Note 12. Article 713 Greek Civil Code.

Note 13. Ministry of Labor and Social Insurance, as provided by the greek legislation.

Note 14. Any Social Cooperative Enterprise that infringes the provisions hereof is imposed with a penalty of five hundred (500) to two thousand (2 000) euros. In case of recidivism, the maximum rate is doubled and the Minister of Employment and Social Security may order the temporary deregistration of such Social Cooperative Enterprise from the Social Entrepreneurship Registry, for a time period from one (1) to six (6) months. In case of further recidivism, such Social Cooperative Enterprise may be permanently deregistered. If the Authority competent for keeping the Registry, as provided in article 14, finds out that legal or natural persons make use of the favorable conditions, as stipulated in article 10, with a view to acquire, for their own account or for the account of third parties, any illegal profit, the Minister of Employment and Social Security shall order for the final deregistration of the Social Cooperative Enterprise where these persons are involved. In addition, the competent region officer will impose a penalty of at least five thousand (5 000) euros to such Social Cooperative Enterprise. The criteria for evaluating this penalty are defined by the joint ministerial decision of paragraph 1, article 17. The imposition of those administrative penalties is irrelevant to any other civil, penal or disciplinary penalty that may be stipulated against the administrative members of the Social Cooperative Enterprise, according to the legislation as currently in force. In the event that a Social Cooperative Enterprise registered in the Social Entrepreneurship Registry infringes the provisions hereof, the regional officer in charge may, upon justified decision, to impose any penalties provided herein or to recommend deregistration of such Social Cooperative Enterprise. The decision on the Social Cooperative Enterprise's deregistration is communicated by the competent Public Economic Authority and the Insurance Funds.

Note 15. Refer to article 268, Law.3463/2006 "Code on Municipalities and Communities". 